\title{
A Manuscript Owned by William Scheves now at Maynooth
}

\author{
Margaret Connolly
}

The recent publication by Peter Lucas and Angela Lucas of a catalogue of the medieval manuscripts in the Russell Library at St Patrick's College, Maynooth (now part of the National University of Ireland), has brought this small collection to wider notice. ${ }^{1}$ The catalogue is generously illustrated and offers extended descriptions of the sixteen manuscripts, three singleleaf fragments, and a number of manuscript fragments recovered from the bindings of printed books. The descriptions are extremely detailed and might be considered exhaustive, but codicological research is often a cumulative process, and there are always new discoveries to be made, sometimes, as in this instance, serendipitously.

In their description of MS RB29, a paper manuscript of the second half of the fifteenth century that contains a compilation of papal decretals and other works, Lucas and Lucas note one instance of an inscription, 'Scheuez', described by them as signed with 'a notarial flourish'. 2 They tentatively interpret this as evidence of a French owner or commissioner of the manuscript, a 'Maître Chevet' ${ }^{3}$ Possibly this also influenced their attribution of the manuscript's origins to

\footnotetext{
${ }^{1}$ Peter J. Lucas and Angela M. Lucas, The Medieval Manuscripts at Maynooth: Explorations in the Unknown (Dublin, 2014); see my review of this volume in The Journal of the Early Book Society (2016), forthcoming. For the Russell Library see https://www.maynoothuniversity.ie/library/collections/russell-library. An overview of the library's collections may be gained from Agnes Neligan, ed., Maynooth Library Treasures (Dublin, 1995); within this volume the manuscripts are described briefly in the essay by Penelope Woods, 'Books rich, rare, and curious', pp. 29-63 (pp. 29-33).

${ }^{2}$ Lucas and Lucas, The Medieval Manuscripts at Maynooth, p. 152.

${ }^{3}$ Lucas and Lucas, The Medieval Manuscripts at Maynooth, p. 153.
} 
France, a place of production that seems likely given that several of the other manuscripts in this small collection are French, including five from Liège. ${ }^{4}$

In fact, the owner of this manuscript was not French, he was Scottish. The inscription is certainly that of William Scheves, archbishop of St Andrews, and one of the most powerful men in Scotland during the reign of James III (1460-1488). Scheves was born c. 1440 and studied and taught at the University of St Andrews before becoming the king's physician. He became archdeacon of St Andrews in 1474, archbishop in 1487, and was made archbishop primate of Scotland in 1487 by Pope Innocent VIII. Scheves died at St Andrews in 1497. 5

Scheves was in the habit of marking his books with a distinctive ownership inscription that consists of his surname superimposed by a double diamond-shaped mark. Lucas and Lucas provide an example of this inscription from p. 419 of MS RB29. ${ }^{6}$ There is also a second, and in fact much clearer example of Scheves's signature on p. 316, see Figure 1. On this leaf the inscription is preceded by six lines of text written in the same ink. Lucas and Lucas correctly note this is a near-contemporary addition to the manuscript, but their description of it as a 'French gothic cursiva' masks the fact this is Scheves's own hand. This may be confirmed by comparison with other known samples of his handwriting; for an extended example see the table of contents that he inscribed at the beginning of his printed copy of Augustine's Tractatus diversi (Antwerp, 1491). ${ }^{7}$

\footnotetext{
4 These have been discussed separately by Peter Lucas and Angela Lucas, 'Lost and found: some manuscripts from Liège now in Maynooth', Scriptorium, 58.1 (2004), 83-99.

${ }^{5}$ Norman Macdougall, 'Scheves, William ( $b$. in or before 1440, d. 1497)', Oxford Dictionary of National Biography, Oxford University Press, 2004, http://www.oxforddnb.com/view/article/24806

${ }^{6}$ Reproduced as Plate 2.2 in Lucas and Lucas, The Medieval Manuscripts at Maynooth, p. 155. The manuscript is paginated.

${ }^{7}$ University of St Andrews Library, Special Collections, TypNL.A85JT; a digital image of sample pages from this book may be viewed as part of the digital exhibition A Royal
} 
Both instances of Scheves's signature in MS RB29 occur at the ends of texts. The first major text of the manuscript begins at the start of quire 2 (p. 17). This is the Compilatio Prima by Bernard of Pavia, a collection of papal decretals divided into five books; it ends on p. 316, at the end of the sixteenth quire, with the addition of the six lines written by Scheves followed by his signature. The second of the manuscript's major texts is Decreta Versificata, in three books. This work occupies six quires in the manuscript, but because the first has been misplaced in the current binding the text is now to be found split between pp. 277-300 (quire 15) and pp. 317419 (quires 17-21). Scheves's signature occurs at the end of this text at the bottom of p. 419. Scheves typically inscribed his name at the beginning of texts or books as well, as may be seen from some of the printed books that he owned, habitually placing this mark of ownership at the top right corner of the first leaf. ${ }^{8}$ He may have followed this practice in MS RB29 too. Although the manuscript has been trimmed, there are indications of disturbance at the top right corners of the two relevant leaves (p. 17 and p. 277), with some traces of ink faintly visible beneath dirt and staining, further obscured by the modern page numbers and, in the case of p. 17, a tear.

Investigation using ultra-violet light reveals traces of Scheves's inscription on p. 277 but does not help distinguish anything futher on $\mathrm{p} .17$. There does seem to have been a deliberate attempt to remove evidence of Scheves's ownership from this volume. The inscription on p. 419 is not merely faded but abraded, as is apparent from its photographic reproduction in the catalogue by Lucas and Lucas. The inscription on p. 316 has survived intact, perhaps because the misplacing of quire 15 served to disguise its presence; although this inscription also stands at the end of a

Foundation: 400 years of the King James Library, https://arts.standrews.ac.uk/digitalhumanities/exhibitions/king-james/early-years.shtml.

${ }^{8}$ This placement of his inscription may be seen in the copy of Augustine's Tractatus diversi cited above, footnote 5 , as well as in other of his books. 
text, the ending of that text is not readily apparent to a reader because of the misordering, and because the two items were copied by the same scribe.

The manuscript's nineteenth-century binding probably obscures further evidence of Scheves's ownership of this volume and where he most likely obtained it. Scheves spent some time in Louvain, certainly towards the end of his life, visiting the city en route to and from Rome in 1490-91 and perhaps earlier in his career as well, though the evidence for this is not clear. He bought books in the city, and also had books bound there, some of which survive in their original bindings. Clear evidence of this may be seen from three incunabula now in St Andrews, one a copy of Pierre d'Ailly's Lecturam sententiarum (printed in Brussels, c. 1483), and the others copies of works by John Chrysostom (both printed by Johannem Koelhoeff de Lubeck at Cologne, 1487). ${ }^{9}$ Although produced elsewhere these volumes were bound in Louvain for Scheves by Ludovicus Ravescot and bear his distinctive rebus of bird and bow. Another volume, a copy of Cassiodorus, Expositio in Psalterium (Basel, 1451) that was owned by Scheves and which survives in the St Andrews collection also preserves an original binding that was made for him in Louvain; and six other works are bound together in a binding that was probably made there. ${ }^{10}$ Amongst manuscripts that he owned, Edinburgh University Library, MS 177, a copy of Geraldus, Super librum nonum almansoris, has a Louvain binding. ${ }^{11}$

Scheves's interest in learning and his reputation as a collector of books was known to his contemporaries, not only in Scotland but also on the Continent. Jasper Laet de Borchloen

\footnotetext{
${ }^{9}$ University of St Andrews Library, Special Collections, TypNB.A8OFA and TypGC.A87KC.

${ }^{10}$ University of St Andrews Library, Special Collections, TypSWB.A91AC. For an example of a Louvain binding see G. D. Hobson, Bindings in Cambridge Libraries: Seventy-Two Plates with Notes (Cambridge, 1929), Plate XII, pp. 34-36.

${ }^{11}$ See C. R. Borland, A Descriptive Catalogue of the Western Mediaeval Manuscripts in Edinburgh University Library (Edinburgh, 1916), pp. 262-63.
} 
dedicated a treatise on astronomy, De eclipsi soli to Scheves and remarked on the valuable library filled with books of every kind that Scheves had assembled in St Andrews. ${ }^{12}$ Recent cataloguing of early printed books in the library at St Andrews under the 'Lighting the Past' initiative has made full information about some of the volumes that still survive there more accessible. A considerable amount is known about the books that belonged to Scheves: in addition to many patristic works he owned a number of medical texts, two copies of the Scotichronicon, the Liber Pluscardensis, a missal, and a Bible. John Durkan listed six manuscripts and twenty incunabula that bear Scheves's signature in an appendix to his study of humanism in Scotland, and in Early Scottish Libraries (with Anthony Ross) offered a slightly emended list of the incunabula alone that raised their number to twenty-three. ${ }^{13}$ One further printed work and a fuller list of eleven manuscripts was given by George Bushnell, who noted the tendency for separate works to be bound together. ${ }^{14}$ In 1981 John Durkan identified four more incunabula, three patristic and one medical, which had belonged to Scheves. ${ }^{15}$ To date a

\footnotetext{
${ }^{12}$ Jaspar Laet de Borchloen, De eclipsi solis anni MCCCCXCI currentis pronosticum (Louvain, 1491). The dedication is printed by C. J. Lyon, History of St Andrews, Episcopal, Monastic, Academic, and Civil, 2 vols (Edinburgh, 1843), II, Appendix 32 (pp. 343-44). The apparently unique surviving copy of Laet's treatise is Edinburgh, Royal Observatory, CR.7.203, see John Higgitt, ed., Scottish Libraries, Corpus of British Medieval Library Catalogues 12 (London, 2006), pp. 235-36, and other references to Scheves passim.

${ }^{13}$ John Durkan, 'The Beginnings of Humanism in Scotland', Innes Review, 4.14 (1953), 5-24. John Durkan and Anthony Ross, Early Scottish Libraries (Glasgow, 1961), pp. 47-49; Plate 1 shows Scheves's inscription on the last leaf of John Cassian, De institutis coenobiorum (Basel [Johann Amerbach], 1485), Blairs College, now University of Aberdeen, Special Collections, BCL S32.

${ }^{14}$ George H. Bushnell, 'Portrait of a Bibliophile IV', The Book Collector, 9 (1960), 19-29. One of the manuscripts in Glasgow University Library listed by Bushnell as MS BE.7, 6, 8 now has the shelfmark General 333; this manuscript was described by N. R. Ker, Medieval Manuscripts in British Libraries (Oxford, 1977), II. 908. See also J. Durkan and R. V. Pringle, 'St Andrews Additions to Durkan and Ross: Some Unrecorded Scottish pre-Reformation Ownership Inscriptions in St Andrews University Library', The Bibliotheck, 9 (1978), 14.

${ }^{15}$ John Durkan, 'Further Additions to Durkan and Ross: Some Newly-Discovered Scottish PreReformation Provenances', The Bibliotheck, 10 (1981), 90.
} 
total of twenty-eight incunabula and eleven manuscripts that were in Scheves's library have been identified, and to this may now be added a twelfth manuscript, Maynooth, St Patrick's College, MS RB29. ${ }^{16}$

St Andrews

Figure 1: Ownership inscription of William Scheves, Archbishop of St Andrews, in St Patrick's College, Maynooth, MS RB29, p. 316. Reproduced by permission of the Librarian, Maynooth University, from the collections of St Patrick’s College, Maynooth.

16 The research for this essay was conducted whilst I was a visiting fellow at the Trinity Long Room Hub Arts and Humanities Research Institute, Trinity College Dublin; I am grateful to the Institute for its support of my research. I also wish to thank Barbara McCormack, Special Collections and Archives, Russell Library, St Patrick's College Maynooth, for assistance during my visits there, and A. S. G. Edwards for helpful suggestions. 